\title{
Article \\ The Effects of DNA Test Results on Biological and Family Identities
}

\author{
Catherine Agnes Theunissen (D)
}

Independent Researcher, Auckland 1010, New Zealand; catherine.a.theunissen@gmail.com

\begin{abstract}
Direct-to-consumer DNA testing is increasingly affordable and accessible, and the potential implications from these tests are becoming more important. As additional people partake in DNA testing, larger population groups and information will cause further refinement of results and more extensive databases, resulting in further potential opportunities to connect biological relatives and increased chances of testers potentially having their identities re-aligned, reinforced or solidified. The effects of DNA testing were explored through 16 semi-structured in-depth interviews conducted with participants who had received their DNA test results. These participants came from diverse groups, genders and ethnic backgrounds. A thematic analysis found that notions of family were frequently challenged with unexpected DNA test results causing shifts in personal and social identities, especially in their family and biological identities. Discrepancies in DNA test results prompted re-negotiation of these identities and affected their feelings of belonging to their perceived social groups. Participants' identities were important to them in varying degrees, with some feeling stronger connections with specific identities, thus having significant re-alignment of these identities and feelings of belonging. This article discusses the thematic analysis's findings and explores how identities of the participants, many of whom took the test for genealogical purposes, were affected by DNA test results. As more people undertake DNA testing, it is important to explore how it may change the notions of family in the future and how their biological and family identities are affected.
\end{abstract}

Keywords: biological identity; family identity; DNA testing; thematic analysis; biogeographic ancestry

Citation: Theunissen, Catherine Agnes. 2022. The Effects of DNA Test Results on Biological and Family Identities. Genealogy 6: 17. https:// doi.org/10.3390/genealogy6010017

Received: 2 December 2021 Accepted: 13 February 2022 Published: 17 February 2022

Publisher's Note: MDPI stays neutral with regard to jurisdictional claims in published maps and institutional affiliations.

Copyright: (C) 2022 by the author. Licensee MDPI, Basel, Switzerland. This article is an open access article distributed under the terms and conditions of the Creative Commons Attribution (CC BY) license (https:// creativecommons.org/licenses/by/ $4.0 /)$.

\section{Introduction}

Direct-to-consumer (DTC) genetic testing is becoming more pervasive as people complete tests to find out more about themselves. Evidently, according to Jhamb (2021), the DTC testing industry is projected to "grow from $\$ 1.4$ billion in 2020 to $\$ 2.6$ billion by 2025 with a compound annual growth rate (CAGR) of $14.2 \%$ for the period of 2020 2025 " (para. 1). This reinforces the growth of the industry and reflects the increase in testing (namely, autosomal, mtDNA and Y-DNA), where the implications from people receiving their results are becoming more complex and, in some cases, changing people's lives. Therefore, exploring the potential implications and effects for people considering taking a test is becoming increasingly important, especially as databases grow and further developments and refinements are made.

This article discusses selected findings from a qualitative research study that interviewed sixteen participants on the effects of DNA tests on their identities. Interviews were semi-structured and in-depth, and the interview data were analysed using thematic analysis. Participants were found through a combination of purposive and snowball sampling, and they had to have completed a DNA test or would be receiving their results during the time of data collection.

The study found that notions of family were frequently challenged, with unexpected DNA test results causing shifts in personal and social identities. This was especially prevalent in family and biological identities, which conforms to views such as that of 
molecular biologist Bernath (2015), who observed the linkages between social identity and biological identity. Bernath (2015) claimed that in the last 20 years, the term 'DNA' has become synonymous with identity. The current study also found that discrepancies in DNA test results prompted re-negotiation of these identities and affected feelings of belonging to their perceived social groups (primarily family and biological groups, which will be the focus of this article). Depending on the importance of their identities, participants who attached stronger significance to specific identities and whose identities were challenged had significant re-alignments of their identities and feelings of belonging when these ideals were challenged.

Identity is a multifaceted concept that has been widely defined and redefined. Although the concept of identity has been explored by a multitude of scholars since Socrates, the term 'identity' was not coined until John Locke (1632-1704) first mentioned 'personal identity' (Coulmas 2019; Izenberg 2016). Much later, in the mid-20th century, 'identity' was popularised by Erik Erikson to describe different forms of identities (Coulmas 2019; Fearon 1999; Harvard University n.d.; Izenberg 2016). While recognising the development of the term, this article focuses on identity as a combination of identities, following the notion that identity is an ongoing process where one adapts to their mutable environmental conditions (Coulmas 2019). This includes the three dimensions of 'self' being closely linked with one's identity, which includes the bodily self (own desires and wishes), relational self (from social and cultural interaction) and the reflective self (where one can observe oneself and relationships) (Izenberg 2016).

Although participants in the current study did not need to specify their type of DNA testing conducted, some participants elaborated on details that were specific to certain types of testing. Many frequently used terms such as 'ethnicity estimates', which are connected to autosomal DNA tests, whereas other participants mentioned specifically looking at their direct paternal or maternal lineages. Thus, to provide context, genetic testing types and DNA tests are introduced, along with five key well-known commercial companies that offer the tests that participants had likely taken. Additionally, although there is a substantial body of knowledge addressing social group identities, Tajfel and Turner's social identity theory is briefly introduced to provide context for key aspects of identity identified by participants.

\section{Genetic Testing Types}

Genetic testing is available in multiple forms, and depending on the purpose of the testing, different tests will yield different results. Genetic testing is conducted by analysing a sample of blood or body tissue (Anzilotti 2021). In the case of DTC tests, these are usually done through a saliva sample, either by spitting into a tube or using a swab. Since the completion of the Human Genome Project in 2003 (National Human Genome Research Institute 2018), DNA tests have become cheaper and easier to access, resulting in further developments. The three main types that participants took included Y-DNA/Y chromosome testing, mtDNA/mitochondrial testing and autosomal testing.

Y-DNA testing only focuses on the paternal line, whereas mtDNA testing looks at the maternal line (van Oven et al. 2013; Schneider et al. 2019). Schneider et al. (2019) explained that markers located on the $\mathrm{Y}$ chromosome were only passed from father to son, which reflected the geographical origin of a male's ancestors. mtDNA, however, is passed down from mothers to sons and daughters, allowing any sex to take the test (van Oven and Kayser 2008). mtDNA testing uses "sequential accumulation of mutations along maternally inherited lineages, which can be represented in a tree reflecting the phylogenetic relationships of known mtDNA variants", which help identify one's maternal lineage (van Oven and Kayser 2008, p. 387). However, a limitation of these tests are that by only focusing on the $\mathrm{Y}$ chromosomes and mtDNA polymorphisms, the tests will only trace back through the particular lineages and not the 16,383 ancestors from up to fourteen generations ago that the person is related to in equal measure (Elliott and Brodwin 2002). Nevertheless, these 
two tests provide potential 'matches' with genetic cousins and a haplogroup assignment indicating the person's placement on the Y-chromosome or mtDNA haplotree.

The third test, the autosomal DNA test, looks at a selection of markers scattered across a person's entire genome and provides matches with genetic relatives from the person's ancestral lines. These tests also provide a biogeographical ancestry estimate based on comparisons with reference populations (Anderson 2021). However, as Schneider et al. (2019) pointed out, the markers located on the autosomes are inherited from both parents and, therefore, reflect the geographic origins of both. They explained that autosomal DNA is reassorted in each generation so that "only half of autosomal DNA markers are still present in each off-spring" (Schneider et al. 2019, p. 877). When biological ancestors come from different regions, autosomal DNA markers can be used to make 'quantitative inferences' about a person's mixed biological ancestry (Schneider et al. 2019). Dooney (2017) wrote that DNA specialist Brad Argent detailed that, as genetic material is passed down from person to person, it can become diluted, especially in a world where people are increasingly diverse.

The further apart the geographic origins of two people are, the greater the differences will be (Schneider et al. 2019). These also reflect migration, where certain DNA markers are seen in particular population groups in specific regions or have commonalities with population groups in certain regions. Due to most human populations having migrated many times throughout history, thereby mixing with nearby groups, the "ethnicity estimates based on genetic testing may differ from an individual's expectations" (Medline Plus 2020, para. 5). Nonetheless, the possibility of different combinations of DNA from the same parents creates complexity and has more possibilities for those using their DNA test results to connect with biological relatives. These forms of testing can be used for DTC tests, where individuals can do a test to gain more information about their ancestry (Best Tests 2014).

Although some participants questioned the validity of the frequently changing ethnicity estimates, they were confident about close matches through centimorgans (cM). The DTC autosomal tests estimate the closeness of relationships through the use of $\mathrm{cM}$. The more DNA is shared, the higher the $\mathrm{cM}$ becomes. Therefore, relatives with high $\mathrm{cM}$ are likely to be more closely linked (Darroch and Smith 2021). This is reflected with 'matches', where testers will be connected to those with a high proportion of shared genetic material (Strand and Källén 2021). The DTC company 23andMe launched the 'relative finding' feature, which used autosomal DNA to show both lines, rather than one's paternal or maternal lineage; soon after, FamilyTreeDNA launched their 'family finder' in 2010 (Darroch and Smith 2021). Since then, multiple DTC companies expanded their markets and now offer various tests.

Genetic testing is, however, not free of controversy. Elliott and Brodwin (2002) stated that genetic information was given too much authority in deciding questions about identity. One's genetic ancestry might not reflect one's identity, they wrote. However, they also pointed out that even though genetic testing could disrupt identity claims, it could corroborate such claims and confirm origin stories, family history or rights to group membership. Argent (as cited in Dooney 2017) added, "[w]e are shaped by the stories of our ancestors, and not necessarily by our genes" (para. 19). In a similar vein, Lawton and Foeman (2017) stated that AncestryDNA was pushing people to the edge of their biogeographical ancestry classifications, giving additional information on how they identified themselves and included a range of factors such as "phenotype, social class, languages spoken, family narratives, and peer relations" (p. 80). Nevertheless, while consumers might be pushed to the edge of biogeographic ancestral classifications, a weakness in DNA testing remains where regions such as Africa, Asia and the Pacific are still under-represented (Dooney 2017) due to many DTC testers being based in other regions and datasets not yet being large or accurate enough in these under-represented areas. However, this may change as testing becomes more popular, accessible and cheaper. As more people take the tests, larger and seemingly more accurate databases are created that will help refine features such as 'ethnicity estimates' and better represent currently under-represented regions. DNA 
testing can also continue to help those who were separated during wars and conflicts or through adoptions, similarly to an experience described by Puig et al. (2019). Puig et al. (2019) detailed how mtDNA testing helped a man find his maternal line and allowed him to reconnect with his family after many decades of separation. This man was one of many people evacuated to Belgium during the Spanish Civil War, and was then adopted into a new family and had his name changed. He was unable to remember his childhood, and DNA testing provided him with the tool to find his biological family.

\section{Commercial Tests Offered}

There are currently five commonly used and well-known DNA companies, namely, AncestryDNA, MyHeritage, FamilyTreeDNA, 23andME and LivingDNA. AncestryDNA (n.d.) offers a DNA test that connects one to relatives and offers ethnicity estimates based on over 1500 regions. Since this study's completion in 2020, AncestryDNA (n.d.) started offering a 'traits' test in the Australasian market, where one can additionally discover biological traits shown in their DNA. MyHeritage (n.d.) offers testing to identify ethnic origins and new relatives. They claim to have a DNA database of 5.4 million people. FamilyTreeDNA offers family ancestry testing, connecting testers with their autosomal DNA relatives within the last five generations and providing a breakdown of origins and where each DNA segment comes from (Gene by Gene, Ltd. n.d.)Gene by Gene, Ltd. Furthermore, they offer mtDNA and Y-DNA testing, which allow the user to be matched with genetic relatives in the databases. (23andMe, Inc. n.d.) offers two main types of testing: 'Ancestry + Traits Service' and 'Health + Ancestry Service'. The first focuses on a person's origins, DNA relatives and 30+ trait reports; the latter test details everything from the first test with additional health predispositions, wellness and carrier status reports. In addition to this, they also include a family health history tree and provide insights into the tester's health based on genetic data. Lastly, similarly to AncestryDNA, LivingDNA Ltd. (n.d.) offers an 'ancestry kit', where the testing shows recent ancestry, sub-regional breakdowns, DNA matching and extended ancestry in one test. This test includes mtDNA and Y-DNA haplogroup reports (haplotypes are found within a haplogroup and are based on DNA information from a mtDNA or Y-DNA test, where specific markers, mutations and variations indicate one's haplotype relationships and help predict a haplogroup, King and Jobling 2009). They also offer a secondary test, which includes an ancestry test with wellbeing, giving additional details on vitamin response, food metabolism and nutrition, exercise and recovery based on the tester's genetic makeup. Tests are region-dependent and are not all available globally. Thus, participants did not always refer to all available tests. They did, however, describe (intergroup) behaviours that demonstrated similarities, which they linked to having a biological connection through DNA.

\section{Intergroup Behaviours and Social Identity Theory}

Intergroup behaviours and the connection with social identity are prevalent in understanding participants' feelings of belonging, group membership and the joining of these aspects to their identities. In the early 1970s, British social psychologist Henri Tajfel and his colleagues conducted minimal-group studies, which showed that people identified as members of a group simply by being categorised into that group (Ellemers 2019). Tajfel and Turner (1979) outlined a theory (social identity theory) to observe intergroup behaviour and intergroup conflict, specifically applying the theory to individual prejudice and discrimination through interpersonal behaviour. Their study elucidated that intergroup conflict or competition facilitated, for instance, greater intragroup morale, which is linked to interpersonal behaviour (Tajfel and Turner 1979).

The 1970 minimal-group studies allowed for the development of social identity theory. Following Tajfel and Turner (1979), scholars have applied the theory across various disciplines. Leaper (2011) stated that the theory addressed the ways in which social identities affected individuals' attitudes and behaviours regarding their ingroup and outgroup membership. The theory has three main dimensions, which include social categorisation, social 
identification and social comparison (Tajfel and Turner 1979). Social categorisation allows individuals to categorise objects to understand their meaning and identify them, helping understand the context and social environment (McLeod 2019; Tajfel and Turner 1979). Social identification occurs when individuals adopt the identity of the group that they have categorised themselves as belonging to, meaning that they conform to the norms of that group and attach emotional significance to their identification with that group (McLeod 2019). This provides a "system of orientation for self-reference" whereby "they create and define the individual's place in society" (Tajfel and Turner 1979, p. 40), as participants did in this study. Social comparison refers to categorising and identifying with a group and comparing one's group with other groups (McLeod 2019). Tajfel and Turner (1979) described social comparison as relational and comparative, defining individuals as 'better' or 'worse' than members of other groups. These dimensions strongly link to social identity and can be applied to understand participants' perceptions of their identities.

Social identity refers to people's self-concepts based on their membership in social groups and how they categorise themselves in social groups (Leaper 2011; Tajfel and Turner 1979). Jenkins (2014) argued that the 'social' part of 'social identity' was redundant and described (social) identity as how individuals identify themselves, depending on the context of the situation. It involves interaction through communication and negotiation (of one's identity). This study found that DNA test results affected participants' social or group identities, making social identity theory valuable in this research and reflecting the varied perspectives that participants held.

\section{Methodology}

A qualitative approach was used in this study to contextualise participants' interviews and their perceptions of their identities. Vaismoradi and Snelgrove (2019) described the aim of qualitative research to help provide "cultural and contextual description and interpretation of [a] social phenomenon" (p. 1). According to Jamshed (2014), interviewing and observations are the most common qualitative methods of data collection. Such interviews can be very open, using narrative interviewing, flexibly structured interviews or focus groups (Scholl 2015). Interviews, as a qualitative method (Cavana et al. 2001), were selected to give further insight into participants' perceptions.

\subsection{Interviews}

Interviews were semi-structured and in-depth, allowing for mutability in participants answers. Part of this process included guiding the participant with open-ended questions and ascertaining when to ask further questions for deeper understanding and context of the participant's narrative (Galletta 2013). Jamshed (2014) described semi-structured interviews as having a partially structured guide of questions that the interviewer would explore during the interview, and in order to optimise time, these guides allow for focused and comprehensive answers from interviewees. Schlütz and Möhring (2015) described in-depth interviews as open-ended interviews, where these types of interviews "reconstruct social events as first-hand experience via storytelling" (p. 302). In the case of the current research, it was important to keep these points in mind and to rearrange questions during the interviews, enabling an interactive approach, allowing for openness of communication and providing opportunities for participants to express their perspectives of how DNA test results affected their identities while also conforming to how Galletta (2013) and Cavana et al. (2001) emphasised the idea of the 'researcher as an instrument', where one can prompt participants, rephrase questions and make changes depending on the interview situation.

Cavana et al. (2001) described face-to-face interviews as information gathering where the interviewer and interviewee meet in person. Interviews were devised to be face to face and were conducted in person where possible as part of the data collection, but with the emergence of easily accessible digital applications, such as Skype, Zoom, Facebook and Microsoft Teams, face-to-face connection could be made visually without meeting in person. Having this face-to-face communication was important in fostering relationships, having 
good communication, giving opportunities for information and questions to be revisited and helping facilitate more open discussion. Participants who were not interviewed in person were interviewed through their preferred video calling channel (usually Facebook Messenger or Skype).

The indicative interview questions are available in Appendix A. Further information about the type of interview (in-person or video call), how long each interview was and the location of each participant during the time of the interview is available in the link to the study mentioned in the 'Data Availability Statement'.

\subsection{Sampling}

In order to find participants, purposive sampling and iterations of snowball sampling were used to connect with possible networks and find further networks where participants would likely fit the inclusion criteria (such as participants completing a DNA test and receiving their results, or would be receiving their results before the interview). For 'purposive' sampling, the size of the sample depended on the number of factors relevant to the study's purpose (Merriam and Tisdell 2016). The researcher initially posted publicly on their Facebook and LinkedIn pages to reach potential participants and allow for sharing across further networks through word of mouth. This is similar to how Audemard (2020) described snowball sampling as involving a first sample of informants who then refer and help recruit participants. Snowball sampling focuses on using two populations: the individual and their relationships (Coleman 1958; Audemard 2020).

To gain a wider reach, multiple groups associated with genealogy were contacted, as genealogists frequently perform DNA tests to assist their research. These included the 'New Zealand Society of Genealogists (NZSG)' and two Facebook pages: 'Genealogy New Zealand and Beyond' and 'Using DNA for Genealogy-Australia \& NZ'. Contacting these networks was similar to applying the snowball sampling method, as it utilised the networks of a designated person branching out (Audemard 2020). As a result, a total of sixteen participants were found for the interviews.

\subsection{Thematic Analysis}

A thematic analysis was used to analyse the interview data. Thematic analysis focuses on themes and patterns in the data, "identifying, analysing, and reporting patterns (themes) within data" (Braun and Clarke 2006, p. 83). Key phases include (1) familiarisation with the data, (2) generating initial codes, (3) searching for themes, (4) reviewing themes, (5) defining and naming themes and (6) producing the report (Braun and Clarke 2006). In order to become more familiar with the data, the audio collected through the interviews was roughly transcribed using otter.ai (an artificial intelligence program that transcribes audio into text) to provide a basic verbatim transcript, along with the use of the video interviews for reference to provide an overall understanding and context.

The researcher manually revised the transcription to remove inaccuracies, and then used verbatim transcripts in conjunction with handwritten notes to identify common semantic features relating to the research question of 'how do DNA test results affect individuals' perceptions of their identity/identities?'. This allowed for the generation of the initial codes by using semantic coding from the transcripts and thereby going through the second phase of Braun and Clarke's (2006) thematic analysis. Vaismoradi and Snelgrove (2019) described the generation of initial codes as being done by highlighting the main ideas as codes in relation to the topic. Braun and Clarke (2019) explained the differentiation between a code and a theme as the code being more specific, capturing a single idea within a segment of data, which can be a 'building block' to create a theme. This type of thematic analysis is commonly a recursive process that moves between each of the six phases; the analytic approach may blend some of these phases together (Braun and Clarke n.d.), as is evident in the latter three phases. A theme "captures a common, recurring pattern across a dataset, clustered around a central organising concept" (Braun and Clarke 2019, p. 2). Further to the semantic content of the data collected, a latent approach delved into the 
understanding of the implicit and underlying meaning, looking at the form and meaning of the data (Braun and Clarke 2006; Lainson et al. 2019). For the purpose of this research, themes were created through a semantic approach. Braun and Clarke (2006) explained this as a process where the researcher identifies themes by looking at the explicit or surface meaning of what the participant has said or written - in this case, what the participants said and what was transcribed. After the development and finalisation of themes, the findings and discussion were produced, thereby enacting the sixth and final phase of the thematic analysis.

\section{Findings and Discussion}

The finalised themes from the full study's thematic analysis included: family belonging, genealogy and ancestry, genetic family connection, family stories, place belonging, group belonging, national pride, unexpected information, cultural affinity and seeking answers. The full findings from the analysis are available through the link in the 'Data Availability Statement'. Although there are elements of overlap between themes, there are distinct aspects to each theme presented in Table 1. This article focuses on family belonging, unexpected information and seeking answers, which are elaborated in the following discussion sections: 'DNA test results reinforcing or contradicting identity claims', 'seeking answers to find family identities' and 'unexpected information prompting identity adaptation'. Moreover, participants will be referred to by their initials throughout the discussion (for instance, CR).

Table 1. Theme summary.

\begin{tabular}{cr}
\hline Theme & Description \\
\hline Family Belonging & $\begin{array}{c}\text { Participants' feelings of belonging to a family or their feelings of } \\
\text { not belonging to their perceived family group and their desire to be } \\
\text { a part of their family[ies]. }\end{array}$ \\
\hline Seeking Answers & $\begin{array}{c}\text { After receiving unexpected information, participants wanted } \\
\text { answers and the truth about family members, specifically their } \\
\text { close family relationships of their parent(s) and/or grandparent(s). }\end{array}$ \\
\hline Unexpected Information & $\begin{array}{r}\text { Participants finding unexpected information as a result of their } \\
\text { DNA tests, creating further interest in seeking answers. }\end{array}$ \\
\hline
\end{tabular}

\subsection{DNA Test Results Reinforcing or Contradicting Family Identity Claims}

Discrepancies in the DNA test results noted by participants prompted re-negotiation of identities and affected their feelings of belonging to their perceived social groups, especially their family and biological groups. For some, the results reinforced their identity claims, whereas those with results contradicting these claims had their identities strongly affected, highlighting how socially constructed groups fostered their belonging and feelings of being connected.

Shim et al. (2018) stated that "[i]deas about oneself in relation to others, perceptions of how others see oneself, one's treatment by others, are all the product of processual, cumulative, lived and indelibly social experiences" (p. 44). Although Shim et al. (2018) focused on racial identity, the notion of having lived experiences constructing one's identity is relevant and applicable to other identities. Participants in this study mentioned communication being used to foster their group belonging, but overwhelmingly mentioned their feelings of belonging to a family group. Family is a socially constructed group, and the feeling of belonging to this group was evident in participants' narratives about their DNA results. Because of their DNA test results, the participants exhibited a change in perception of their family identity or, in some cases, adopted multiple family identities when their DNA results were different from their family identity claims. For instance, when KB learned that her biological father was someone different, she consequently met her biological father and his two children, along with another half-sister from another family (fathered by her 
biological father), as well as her grandmother and cousins. She also expressed occasionally feeling a lack of belonging in the family she was raised in, feeling left out of gatherings, especially during a family event in which her grandmother commented that her father was the local pub owner, which "scared" her.

'Family' is defined by LEXICO (n.d.) as meaning "[a] group of one or more parents and their children living together as a unit" (para. 1) or "[a]ll the descendants of a common ancestor" (para. 4). More recently, a further definition was added: "a group of related things" (LEXICO n.d., para. 7); this encapsulates the changing notions of family. Participants used these three definitions interchangeably when talking about their immediate family and extended family through DNA matches, as well as their biological family and the family in which they were raised.

A lack of belonging to their 'family' was usually due to a change in their perceived identity through unexpected DNA test results. In many cases, the unexpected results prompted an identity crisis (the disturbances that disrupt the self) and affected their ego identity (the psychic structure fundamental to psychological equilibrium) (Coulmas 2019; Fearon 1999; Harvard University n.d.; Izenberg 2016). Although these disruptions were not age-specific, they disturbed the sense of self and contributed to who they believed themselves to be, thereby affecting their wider relationships.

For example, CR felt that she had a significant change in her perceived identity after her DNA test did not show DNA matches with her expected biological grandfather. She stated that a quarter of who she thought she was now unknown. By exploring the possibilities of the unknown quarter, she was re-evaluating her family relationships and who she was as a member of this familial group. Her actions displayed a disruption in her sense of self and expressed elements of social identity theory. As described prior, social identity theory refers to the interplay between personal and social identities and attempts to specify and predict the circumstances of how one perceives oneself as an individual or as a group member (Ellemers 2019; McLeod 2019). Tajfel and Turner (1979) described the feeling of membership as 'social identity', whereby one's self-image is derived from the social categories to which individuals perceive themselves as belonging. This can be seen through CR's feeling of having a significant change in her perceived identity and her questioning of what her biological family would be like, even though she loved the family that raised her. This reinforces the idea that identities are most important when individuals feel that they have strong emotional ties to a group and have membership with that group, thereby reinforcing their self-esteem, which sustains their social identity (Leaper 2011). Disruption, therefore, caused participants such as CR to re-evaluate these emotional ties and the effects on their identities.

One of the three dimensions of social identity, social categorisation, was evident in the way that CR categorised her family relationships when referring to her "biological family" and the family that raised her and, therefore, categorising these relationships to understand her context and social environment (McLeod 2019; Tajfel and Turner 1979).

CR had revisited her DNA results and looked at the names only to find that her grandfather was not her biological grandfather; she mentioned, "It's impacted me immensely because a quarter of who I thought I was I'm not and it's a very odd sensation; it's an odd feeling in not knowing now". She added that she was surprised how much it impacted who she believed herself to be, as her whole family line from Manchester, England was no longer what she thought it was. By acknowledging these separate categories, CR became associated with two family identities, which shows how DNA test results can solidify or separate familial identities.

$\mathrm{CR}$ further questioned what her biological family would be like, comparing herself to the two families and looking for potential similarities. This process has some semblance with social comparison, another dimension of social identity theory. This dimension refers to categorising and identifying with a group and comparing that group to other groups, which are usually relational (McLeod 2019; Tajfel and Turner 1979). In this case, CR described her membership in her biological family and the family that raised her as having 
membership in two different groups-one in a biological sense, and the other in what she had believed to be her family identity. Effectively, she socially compared herself, redefined her group belonging and associated herself with two distinct family groups.

CR also used the term "love" in aligning herself with the family that she was raised in and described feeling a sense of belonging, which was much like how $\mathrm{NH}$ described feelings of belonging when asking her grandmother questions about their relations and how RG talked about one of her favourite stories because it showed their family having fun together:

My uncles would play the fiddle, and all those little things, I don't even know the proper names of everything, and we would have things like barn dances. So that was who I was growing up.

These participants associated themselves with a family group and their positive shared experiences, describing the relational element that made them feel included and part of the family. This is similar to achieving satisfactory group identification, which can be described as a sense of belonging formed by group identities that are relational and that include peers and exclude others (Coulmas 2019). Walker (2015) also described love as having a crucial role in "a sense of safety and belonging" (p. 102). Although Walker's (2015) research focused on child adoptees, the feeling of belonging to a family is relevant to these participants' perceptions of their identity and reflects that belonging is often intertwined with strong emotions-in this case, positive emotions.

It was evident that relationships were reflected on by these participants, reinforcing the idea that families have their own group boundaries and identities. Soliz and Harwood (2006) described families as having 'intergroup' and 'intragroup' relationships, where family members share an inherent ingroup for all members, but also have individual identities that show intragroup boundaries within the family. Thus, participants' positive emotive affiliations reinforced their family belonging and the relationships within each family group, even when familial identities were separated. The participants' narratives demonstrated that they looked for inclusion in order to retain separate identities or placed more value on their biological identity. When this inclusion was disrupted, as was the case for certain participants, their sense of identity was affected.

For example, BD had identified with the English side of her family until she was nursing someone with haemophilia and her mother was prompted to tell her that she [the mother] was adopted. BD recounted that she was "horrified because I love my grandparents. That to me, it was huge. Suddenly they weren't my grandparents". This demonstrates another dimension in social identity theory, namely, social identification. Social identification occurs when individuals adopt the identity of the group they have categorised themselves as belonging to by conforming to the norms of the group and attaching an emotional significance to their identification with the group (McLeod 2019). This dimension also provides a reference for an individual to create and define their place in society (Tajfel and Turner 1979). Therefore, with participants attaching emotional significance to their identification with their social (and familial) identities, unexpected information as in the cases of $\mathrm{CR}$ and $\mathrm{BD}$ can change perspectives and the ways that they identify themselves. This may lead to feelings of exclusion from their perceived family groups.

Although DNA test results can cause this drastic change in social and familial identities, DNA matches also allowed these participants to try to get in contact with those who could help them find more information, thus allowing for inclusion in another group and a sense of belonging within their 'current' family. These matches can mitigate the effect of an identity crisis by providing answers and support. CR and BD expressed "love" for their family members, suggesting strong emotional attachment, and thus, it was a greater shock to find out their biological identities did not match their perceived family identities. However, JG also experienced misalignment of these identities, but said that the results and new information about her biological father not being who she thought did not affect her. JG said she felt "very fortunate" because "they were both so much older". Her mother was 
thirty-seven, and both her biological father (the local gynaecologist) and the father who she had been raised by were both in their fifties when she was born. From this, she said:

I didn't do a lot with my father, with my legal father. I could count on one hand the number of times we actually went and did something together, just us together because he was so much older.

She was aware that her mother wanted a child and was struggling to have one, so she believed that her biological father was a "pioneer in gynaecology and women's reproductive systems. And [it was] very well known that the women of Wagga thought he was just wonderful. I don't know what that might mean." JG said that she loved the family she grew up in and was still happy to be in contact with them, showing that the participants articulated different impacts on their identities. A positive emotional significance can reinforce family belonging by fostering relationships and strengthening family identities. However, it can also cause re-evaluation of this identity and individuals' belonging within the group.

It can be argued that the notions of family are continually shifting and cannot be clearly outlined, as is evident with the addition of the definition of 'family' to LEXICO's (n.d.) dictionary. This is similar to Isensee's (2015) claim that notions of family have come under more scrutiny in recent years, as family was usually defined within the nuclear family dynamic (consisting of married parents and their biological or adopted children). However, family is socially constructed and the participants had varied perceptions on what constituted their families.

LEXICO's (n.d.) additional definition of family that describes a 'group of related things' shows that notions of family are changing, allowing for more variance than the original definition of purely being part of a 'family unit' or 'descendants of a common ancestor'. It also demonstrates that definitions of family may be different from one's familial or biological identities. In some cases, such as those of KB, CR, BD and JG, participants may have lived in a family unit when DNA test results revealed that the family they thought they belonged to was not fully biologically connected. Nevertheless, they still associated this unit with one of their family identities. This reframing of their family identities conforms with claims from authors such as Stallard and Groot (2020, p. 289), who stated that DNA test results:

can be disruptive, and often individuals are resistant to redefining the family group. In the case of special groups like adoptees, those with unknown parents, those with half-sibs and stepsiblings, new information can shatter the model of family identity that had been built up for many years.

With DNA test results having an immediate effect on test takers' lives, they have increased the likelihood of disrupting their senses of self and group belonging whilst forming connections to other identities and shared experiences. This is in line with some concluding remarks made by Shim et al. (2018), where they found that "participants' racial identities emanated from their cumulative, personal, familial and social life experiences-and therefore as discrete from information they received from a singular source (their genetics) at one point in time" (p. 58).

\subsection{Seeking Answers to Find Family Identities}

For most participants with substantial changes in their perceived family identities (unexpected results about parents or grandparents), there was a significant change in the sense of self and a desire to seek the truth. They sought answers about their family members to help them understand who they were and where they belonged. In other words, there was a change in their familial and personal identities. For example, JG had unexpected results about her biological father, but she was able to use her DNA matches to find some of the answers to her questions. Comparatively, $\mathrm{CR}, \mathrm{KB}$ and $\mathrm{BD}$ all wanted further answers and explanations for why their DNA tests revealed unexpected results. Their families 
had not discussed the possibilities or were not able to give clarity about why there were unexpected results.

When CR found out that her biological grandfather was not who she thought, she reflected on "this whole family I never got to know and I still don't know. How do I build that connection now?". KB, who found that her biological father was not who she thought and who has since reconnected with biological family members, said for a long time that she felt "robbed" of what could have been her life if she had been raised with her biological sisters or father. Connections to people were clearly important to her sense of self. She did, however, say that she had worked through it and, in the end, felt that she "had the best possible life" and that she was "grateful" for the life she had. These emotive phrases correspond with affective understanding in looking at belonging in the context of others, which is in line with Wood's and Black's (2016; as cited in Turner 2019) research.

This shows the affective understanding and importance of relationships to one's identities and, importantly, how disruption affects a person's sense of identity. The connection through family that CR mentioned and the participants' use of affective and emotive language when describing their family connections reaffirm that family is one of the most fundamental and important social groups for individuals (Soliz and Harwood 2006; Colaner et al. 2018).

For some, family may be the most important social group, but other social groups can also hold strong importance. Belonging is important for participants' identities (Wood and Black 2016; as cited in Turner 2019). Thus, feeling belonging through relationships seems to be a fundamental aspect that resonates with various social groups, including family. The degree to which people perceive themselves as part of an in-group (such as a family) and have shared relational culture is important, thereby marking their identification with the group (Soliz and Rittenour 2012; as cited in Colaner et al. 2018). As the intergroup research of Soliz et al. (2009) revealed, there were benefits to individuals forming a cohesive shared family identity because it facilitated a shared belonging within a family.

Participants' questioning of their shared family identities resulted in more questions about themselves as individuals, as was the case with CR and BD. Without answers to their questions, participants used further emotive words to describe their feelings of emptiness. CR felt "vacant" and said, "we [she and her mother] feel like we're in limbo". KB and $\mathrm{BD}$ also expressed a shift in their perception of who they thought they were and wanted answers. BD articulated a similar sense of emptiness to that of CR, but was able to find partial answers, as she had met her biological grandfather's family, although she was still searching for her biological grandmother's identity. These participants wanted truthful answers in order to understand their own place within the family and their individual identities to find out where they came from, as well as their relationships and connections with their parents/grandparents. This was much like how Stallard and Groot (2020) described how those who were searching for parents or grandparents (such as BD, who was looking for her birth grandfather) used DNA tests to "discover results that could significantly reconfigure their familial identity and relationships" (p. 287). These findings highlighted the importance of familial relationships in determining one's belonging and the role of DNA testing in helping achieve this.

Having strong relationships with parents and grandparents resembles Soliz and Harwood's (2006) study on shared family identity. Their study focused on the grandparentgrandchild relationship, showing that "personal communication emerged as a strong influential factor in perceptions of shared family identity across all grandparents" (p. 100). Therefore, a strong relationship with one's grandparents and, in this case, one's parents increases the likelihood that those who have undergone a substantial shift will have to realign their perceived shared family identities.

Again, these findings reinforce the importance of relationships and feelings (affective understanding) as part of belonging (Wood and Black 2016; as cited in Turner 2019).

There are similarities with how Nash (2004) described the increased popularisation of genetic testing as creating 'genetic kinship' and how this knowledge creates "new 
definitions of gender, 'race' and relative that reinforce, reshape or challenge existing notions of collective identity and personhood" (p. 4). Since then, the latter was most important in relation to participants who were seeking answers about their family identities. Having 'genetic kinship' allows for a sense of group belonging, and similarities in DNA create a sense of potential connection and possible relationships.

\subsection{Unexpected Information Prompting Identity Adaptation}

In this study, the majority of the participants' stories showed that DNA tests affected individuals' perceptions of their identities. Unexpected information as a result of these tests was undoubtedly one of the most prominent factors.

However, such discoveries through DNA testing also prompted interest in exploring possible identities. $\mathrm{CH}$ wanted to find her Korean origins because no one in her family was aware of the connection. Similarly, NH said that she had very unexpected results, with her ethnicity estimates showing $20 \%$ Italian. She assumed this could be connected to her maternal grandfather's side, about whom she did not know much, but she was surprised that her two brothers did not have any Italian in their estimates. AV was also surprised by her "Baltic blood", showing "Lithuania and Latvia" in her ethnicity estimates. She had expected Russia and maybe some estimates from Ukraine, Poland or Slovakia, but hoped for something such as Brazil. $\mathrm{CH}, \mathrm{NH}$ and $\mathrm{AV}$ alluded to their biogeographic ancestry and biological identity making them feel connected to an area, with their tests prompting interest in learning more about these areas and their relationships with their family identities. Instead of changing their perceived identities, they showed an interest in broadening their understanding of their own identities.

DJ's Y-DNA test results allowed him to find a Scottish connection with his paternal haplogroup, which had "never entered into the conversation", thus forming his Scottish pride, as well as a feeling of belonging to a new clan and being biologically connected to family through one lineage. Other family relationships were also fostered through unexpected information. CR revisited her DNA test results and was surprised about the impact that this had on her, as she questioned her personal and family identities.

As mentioned earlier in this article, participants' use of emotive phrases reflected their affective understanding of exploring their belonging (Wood and Black 2016; as cited in Turner 2019). Participants expressed that the unexpected results created varied emotions, with most being "surprised" by their ethnicity estimates. Others who had to renavigate their family relationships seemed to have a more substantial emotional disturbance in their senses of self, as evidenced by CR saying that it impacted her "immensely because a quarter of who I thought I was I'm not". Disruption in her identity was evident with her unexpected results, showing that there was an emotional fallout when receiving confusing or life-changing test results, where "[i]dentities that have been cherished by families for generations can be dismantled overnight" (Lawton 2018, para. 6). As more people take DNA tests, the possibility of identity disruption is becoming increasingly likely.

Despite being an adult, CR also expressed genealogical bewilderment, which can be described as "potential identity problems that can be experienced by a child who has been separated from her birth parents" (Walker 2015, p. 93). Whilst she was not separated from her birth parents, she exhibited the overall meaning of the term, where genealogical bewilderment may include questions about who one is and where one belongs (Walker 2015).

KB also experienced genealogical bewilderment. She connected with new biological family members after coming to terms with her unexpected results, finding another halfsister on her paternal side although her biological half-sister's parents denied the validity of the test. Her experience conformed to Stallard and Groot's (2020) assertion that those receiving DNA test results can be resistant to having to redefine their family groups. Although KB redefined her new belonging within another family (her biological family) and attempted to help her newfound biological half-sister renavigate identities, her halfsister's family did not. In terms of relationships, feeling and space (Wood and Black 2016; 
as cited in Turner 2019), KB renegotiated her identity, helping another biologically related individual in the same situation. This reinforced the potential of DNA complicating the notion of family while also broadening possibilities (Stallard and Groot 2020).

Likewise, JG found a DNA match that was likely to be her half great niece, which led her to find out that there was a problem with her birth father (as she did not have any siblings). She described this as "completely and absolutely, and utterly unexpected". When she did further research, she found that her biological father was the local gynaecologist in the town in which she was born, and so believed that her birth may have been the result of him being a "pioneer in gynaecology" (suggesting that he may have had an understanding about practices such as artificial insemination). However, JG seemingly focused her realignment of her identity with her autobiographical completeness, trying to understand her unexpected results and how they shaped her understanding of self, whereas $\mathrm{CR}$ and $\mathrm{KB}$ had to re-evaluate their family identities and new relationships, rather than solely focusing on their autobiographical completeness. Autobiographical and genealogical connectedness were mentioned by Walker (2015), who wrote about children's psychological development, where one uses elements of connectedness to create a sense of belonging, a coherent sense of self and a clear identity.

\section{Conclusions}

This study highlighted some of the effects of DNA test results on participants' identities. Belonging to a family group and feeling 'connected' were key elements in participants' sense of self and transcended multiple identities.

With genetic testing revealing DNA matches that increase as more biological relatives take the test, people who test in the future may also have unexpected results, forcing them to renegotiate their family identities. This may be beneficial to some testers, but could equally change their perspectives. These test results may increase their feeling of inclusion in a (family) group and, therefore, their feeling of a sense of belonging to their family, or they may feel excluded and look for answers. They may even feel a certain degree of belonging to both their biological relatives and the family that they grew up with, thus changing their perception of their family[ies] and what constitutes their family identity[ies]. Feelings of belonging with multiple group identities elucidate the changing notions of family.

'Family' increasingly encapsulates multiple identities and will continue to be challenged and refined as more DNA tests are taken and further developments are made with genetic technology. Even though aspects of family may be biologically shaped, the lived-in environments are equally important in determining one's feeling of belonging and connection. Relationships were evidently important, with biological connections reaffirming participants' identities and discrepancies altering their relationships and perspectives of personal and group identity.

Recommendations for future research include looking at how DNA test results affect further disruptions in identity, including cases such as individuals who were separated from families through wars and conflicts, as well as adoptions. Looking at their perceived identities and feelings of belonging would be a useful addition for understanding the importance of lived-in and biological family and relationship dynamics.

Overall, participants' associations were positive and inquisitive. Despite some unexpected results, they all acknowledged new or different aspects of their identities, prompting some identity re-alignment. In some cases, unexpected results were not as significant to their senses of self or group belonging because they attached more importance to other identities. Individuals hold multiple identities, each with their own importance, and the participants were ultimately looking for some semblance of belonging or connection.

Funding: This research received no external funding.

Institutional Review Board Statement: This research obtained ethics approval 19/301 from the Auckland University of Technology Ethics Committee on 10 September 2019. 
Informed Consent Statement: Informed consent was obtained from all subjects involved in the study.

Data Availability Statement: Full findings, appendices of interviews, questions and participant summaries are available at https: / / openrepository.aut.ac.nz/handle/10292/14111 (accessed on 2 December 2021).

Acknowledgments: A substantial thank you to all the participants who shared their stories as part of this research. Also, a thank you to the New Zealand Society of Genealogists (NZSG), and the two Facebook groups 'Genealogy New Zealand and Beyond' and 'Using DNA for Genealogy-Australia \& NZ', who helped facilitate the finding of participants.

Conflicts of Interest: The author declares no conflict of interest.

\section{Appendix A}

Indicative questions used in the interviews:

- $\quad$ Can you tell me a story that resonates with your identity?

- How did your DNA test results affect this?

- Do you feel like it impacted your identity in any other ways?

- Did you find out anything about yourself that was unexpected?

- What test did you take and what did you initially expect?

- Has the test changed your perspective at all?

- $\quad$ Since you got the DNA test results, do you have a recent story that resonates with your identity (whether it's the same or changed)?

- Will you be taking any further steps to get more information since the DNA test or is this a one-off?

- Is there anything you'd like to add?

\section{References}

23andMe, Inc. n.d. 23andMe Homepage. Available online: https://www.23andme.com/ (accessed on 22 November 2021).

AncestryDNA. n.d. Uncover More of Your Story. Available online: https:/ /www.ancestry.com.au/dna/ (accessed on 20 November 2021).

Anderson, Alyssa. 2021. What Are Autosomal DNA Tests? WebMD. Available online: https://www.webmd.com/a-to-z-guides/ what-are-autosomal-dna-tests (accessed on 9 November 2021).

Anzilotti, Amy W. 2021. Genetic Testing. Kids Health from Nemours. Available online: https://kidshealth.org/en/parents/genetics. html (accessed on 6 February 2022).

Audemard, Julien. 2020. Objectifying contextual effects. The use of snowball sampling in political sociology. BMS: Bulletin de Methodologie Sociologigue 145: 30-60. [CrossRef]

Bernath, Viviana. 2015. Social Identity and Biological Identity. Translated by Jane Ramirez. Ann Arbor: U-M Center for Latin American and Caribbean Studies, vol. 3, pp. 35-86. [CrossRef]

Best Tests. 2014. Genetic Health Services New Zealand (GHSNZ): What You Need to Know. BPAC Medicine. Available online: https:/ / bpac.org.nz/BT/2014/November/docs/BT25-ghsnz.pdf (accessed on 25 November 2021).

Braun, Virginia, and Victoria Clarke. 2006. Using thematic analysis in psychology. Qualitative Research in Psychology 3: 77-101. [CrossRef]

Braun, Virginia, and Victoria Clarke. 2019. Answers to Frequently Asked Questions about Thematic Analysis. The University of Auckland. Available online: https://cdn.auckland.ac.nz/assets/psych/about/our-research/documents/Answers\%20to\%20 frequently\%20asked\%20questions\%20about\%20thematic\%20analysis\%20April\%202019.pdf (accessed on 8 October 2019).

Braun, Virginia, and Victoria Clarke. n.d. Thematic Analysisa Reflexive Approach. The University of Auckland. Available online: https:/ / www.psych.auckland.ac.nz/en/about/thematic-analysis.html (accessed on 8 October 2019).

Cavana, Robert Y., Brian L. Delahaye, and Uma Sekaran. 2001. Applied Business Research: Qualitative and Quantitative Methods. Hoboken: Wiley.

Colaner, Colleen Warne, Haley Kranstuber Horstman, and Christine E. Rittenour. 2018. Negotiating adoptive and birth shared family identity: A social identity complexity approach. Western Journal of Communication 82: 393-415. [CrossRef]

Coleman, James S. 1958. Relational Analysis: The Study of Social Organizations with Survey Methods. Human Organization 17: 28-36. Available online: https:/ /www.jstor.org/stable/44124097 (accessed on 5 October 2019). [CrossRef]

Coulmas, Florian. 2019. Identity: A Very Short Introduction. Oxford: Oxford University Press. [CrossRef] 
Darroch, Fiona, and Ian Smith. 2021. Establishing Identity: How Direct-To-Consumer Genetic Testing Challenges the Assumption of Donor Anonymity. Family Court Review 59: 103-20. Available online: https://onlinelibrary.wiley.com/doi/epdf/10.1111/fcre.12 553 (accessed on 5 February 2022). [CrossRef]

Dooney, Laura. 2017. Native Affairs Reveal DNA Test of Full-Blooded Māori Woman. Stuff NZ. Available online: https:/ /www.stuff. co.nz/national/91480531/native-affairs-reveal-dna-test-of-fullblooded-maori-woman?rm=m (accessed on 12 April 2017).

Ellemers, Naomi. 2019. Social Identity Theory. In Encyclopaedia Britannica. Available online: https://www.britannica.com/topic/socialidentity-theory (accessed on 4 January 2019).

Elliott, Carl, and Paul Brodwin. 2002. Identity and genetic ancestry tracing. BMJ 325: 1469-71. [CrossRef] [PubMed]

Fearon, James D. 1999. What Is Identity (as We Now Use the Word)? Stanford: Stanford University. Available online: https: //web.stanford.edu/group/fearon-research/cgi-bin/wordpress/wp-content/uploads/2013/10/What-is-Identity-as-wenow-use-the-word-.pdf (accessed on 20 October 2019).

Galletta, Anne. 2013. Mastering the Semi-Structured Interview and beyond: From Research Design to Analysis and Publication. New York: New York University Press. Available online: https://www.jstor.org/stable/j.ctt9qgh5x (accessed on 10 October 2019).

Gene by Gene, Ltd. n.d. FamilyTreeDNA Homepage. Available online: https:/ /www.familytreedna.com/ (accessed on 22 November 2021).

Harvard University. n.d. Erik Erikson (1902-1994). Available online: https://psychology.fas.harvard.edu/people/erik-erikson (accessed on 7 April 2020).

Isensee, Reinhard. 2015. Introduction. In Family and Kinship in the United States, Cultural Perspectives on Familial Belonging, 1st ed. Edited by Karolina Golimowska, Reinhard Isensee and David Rose. Location: Peter Lang Edition, pp. 7-14.

Izenberg, Gerald. 2016. Identity, the Necessity of a Modern Idea. Pennsylvania: University of Pennsylvania Press.

Jamshed, Shazia. 2014. Qualitative research method-interviewing and observation. Journal of Basic and Clinical Pharmacy 5: 87-88. [CrossRef]

Jenkins, Richard. 2014. Social Identity, 4th ed. London: Routledge.

Jhamb, Kamna. 2021. Direct to Consumer Testing Industry Global Markets (HLC269A). BCC Publishing. Available online: https: //www.bccresearch.com/market-research/healthcare/direct-to-consumer-testing-market.html (accessed on 16 November 2021).

King, Turi E., and Mark A. Jobling. 2009. What's in a name? Y chromosomes, surnames and the genetic genealogy revolution. Trends in Genetics 25: 351-60. [CrossRef]

Lainson, Kristina, Virginia Braun, and Victoria Clarke. 2019. Being Both Narrative Practitioner and Academic Researcher: A Reflection on What Thematic Analysis Has to Offer Narratively Informed Research. International Journal of Narrative Therapy and Community Work 4: 86-98. Available online: https:/ / uwe-repository.worktribe.com/output/4820836/being-both-narrative-practitioner-andacademic-researcher-a-reflection-on-what-thematic-analysis-has-to-offer-narratively-informed-research (accessed on 15 October 2019).

Lawton, Bessie, and Anita Foeman. 2017. Shifting Winds: Using Ancestry DNA to Explore Multiracial Individual's Patterns of Articulating Racial Identity. Identity 17: 69-83. [CrossRef]

Lawton, Georgina. 2018. It Made Me Question My Ancestry': Does DNA Home Testing Really Understand Race? The Guardian. August 11. Available online: https:/ / www.theguardian.com/lifeandstyle/2018/aug/11/question-ancestry-does-dna-testing-reallyunderstand-race (accessed on 29 September 2019).

Leaper, Campbell. 2011. More similarities than differences in contemporary theories of social development? Advances in Child Development and Behaviour 40: 337-78. [CrossRef]

LEXICO. n.d. Definition of Family in English: Family. In Oxford English and Spanish Dictionary, Thesaurus, and Spanish to English Translator. Available online: https:/ /www.lexico.com/en/definition/family (accessed on 29 November 2021).

LivingDNA Ltd. n.d. The Most Advanced DNA Test to Discover Your Ancestry. Available online: https://livingdna.com/nz/kit/ ancestry-dna-test (accessed on 22 November 2021).

McLeod, Saul A. 2019. Social Identity Theory. Simply Psychology. October 24. Available online: https://www.simplypsychology.org/ social-identity-theory.html (accessed on 10 February 2020).

Medline Plus. 2020. What Is Genetic Ancestry Testing? In NIH U.S. National Library of Medicine; September 21. Available online: https:/ / ghr.nlm.nih.gov/primer/dtcgenetictesting/ancestrytesting (accessed on 20 September 2020).

Merriam, Sharan B., and Elizabeth J. Tisdell. 2016. Qualitative Research: A Guide to Design and Implementation, 4th ed. San Francisco: Jossey-Bass.

MyHeritage. n.d. Discover Your Family Story. Available online: https:/ / www.myheritage.com/dna (accessed on 22 November 2021).

Nash, Catherine. 2004. Genetic kinship. Cultural Studies 18: 1-33. [CrossRef]

National Human Genome Research Institute. 2018. Human Genome Project Timeline of Events. Available online: https://www. genome.gov/human-genome-project/Timeline-of-Events (accessed on 12 April 2020).

Puig, Pere, Anna Barceló, Roger Lahoz, Àngels Niubó, Jimi Jiménez, Montserrat Soler-López, Michael J. Donovan, Joaquima Navarro, Jordi Camps, Montserrat Garcia-Caldés, and et al. 2019. Genetic identification of a war-evacuated child in search of his own identity for more than seventy years. Forensic Science International 298: 312-15. [CrossRef] [PubMed]

Schlütz, Daniela, and Wiebke Möhring. 2015. Interview, Qualitative. In The Concise Encyclopaedia of Communication, 1st ed. Edited by Wolfgang Donsbach. Hoboken: John Wiley \& Sons, Inc., pp. 301-2. 
Schneider, Peter M., Barbara Prainsack, and Manfred Kayser. 2019. The use of forensic DNA phenotyping in predicting appearance and biogeographic ancestry. Deutsches Aerzteblatt International 116: 873-80. [CrossRef]

Scholl, Armin. 2015. Qualitative Methodology. In The Concise Encyclopaedia of Communication, 1st ed. Edited by Wolfgang Donsbach. Hoboken: John Wiley \& Sons, Inc., pp. 510-12.

Shim, Janet K., Sonia Rab Alam, and Bradley E. Aouizerat. 2018. Knowing something verses feeling different: The effects and non-effects of genetic ancestry on racial identity. New Genetics and Society 37: 44-66. [CrossRef]

Soliz, Jordan, Allison R. Thorson, and Christine E. Rittenour. 2009. Communicative correlates of satisfaction, family identity, and group salience in multiracial/ethnic families. Journal of Marriage and Family 71: 819-32. [CrossRef]

Soliz, Jordan, and Christine E. Rittenour. 2012. Family as an intergroup arena. In The Handbook of Intergroup Communication. Edited by Howard Giles. London: Routledge, pp. 331-43.

Soliz, Jordan, and Jake Harwood. 2006. Shared family identity, age salience, and intergroup contact: Investigation of the grandparentgrandchild relationship. Communication Monographs 73: 87-107. [CrossRef]

Stallard, Matthew, and Jerome de Groot. 2020. "Thing are coming out that are questionable, we never knew about": DNA and the new family history. Journal of Family History 45: 274-94. [CrossRef]

Strand, Daniel, and Anna Källén. 2021. I am a Viking! DNA, popular culture and the construction of geneticized identity. New Genetics and Society 40: 520-40. [CrossRef]

Tajfel, Henri, and John C. Turner. 1979. An Integrative Theory of Intergroup Conflict. In The Social Psychology of Intergroup Relations. Edited by William G. Austin and Stephen Worchel. Monterey: Brooks/Cole, pp. 33-47.

Turner, Marie. 2019. Inclusion and Autism, Belonging. In Belonging: Rethinking Practices to Support the Well-Being and Identity. Edited by Annie Guerin and Trish McMenamin. Leiden: Brill Sense, pp. 25-50.

Vaismoradi, Mojtaba, and Sherrill Snelgrove. 2019. Theme in qualitative content analysis and thematic analysis. FQS, Forum: Qualitative Social Research 20: 23. [CrossRef]

van Oven, Mannis, and Manfred Kayser. 2008. Updated comprehensive phylogenetic tree of global human mitochondrial DNA variation. Human Mutation, Mutation in Brief 30: E386-E394. [CrossRef] [PubMed]

van Oven, Mannis, Anneleen van Geystelen, Manfred Kayser, Ronny Decorte, and Maarten H. D. Larmuseau. 2013. Seeing the wood for the trees: A minimal reference phylogeny for the human Y chromosome. Human Mutation 35: 187-91. [CrossRef] [PubMed]

Walker, Jim. 2015. Establishing a sense of belonging for looked after children: The journey from fear and shame to love and belonging. In Towards Belonging: Negotiating New Relationships for Adopted Children and Those in Care. Edited by Andrew Briggs. Abingdon: Taylor \& Francis, pp. 85-103. 